\title{
Effects of hyperthermia on the effective concentration of rocuronium and sugammadex-mediated reversal in isolated phrenic nerve hemidiaphragm preparations of rats
}

Jin Sun Kim², Young Mu Kim, Ha Jung Kim², Jae Moon Choi ${ }^{2}$, Yong Beom Kim³ , Jae Seok Song ${ }^{4}$ and Hong Seuk Yang ${ }^{5^{*}}$ (D)

\begin{abstract}
Background: Hyperthermia is relatively rare during general anesthesia; however, a few studies have been conducted on hyperthermia and the neuromuscular blockade (NMB) induced by rocuronium, and the reversal of NMB by sugammadex. We investigated the effect of hyperthermia status on the NMB induced by rocuronium, and its reversal by sugammadex, in isolated phrenic nerve hemidiaphragm (PNHD) preparations of the rat.

Methods: Thirty-three male Sprague-Dawley rat PNHD preparations were randomly assigned to three groups at different temperatures $\left(36^{\circ} \mathrm{C}, 38^{\circ} \mathrm{C}\right.$, and $40^{\circ} \mathrm{C}$; each group, $n=11$, in Krebs solution). The train-of-four (TOF) and twitch height responses were checked mechanomyographically. The PNHD were treated with progressively increasing doses of rocuronium and three effective concentrations (ECs), EC50, EC90, and EC95, of rocuronium were analyzed in each group via nonlinear regression analysis. Then, sugammadex was administered in doses equimolar to rocuronium. Thereafter, the T1 height (\%), TOFR (\%) and the duration index were measured.

Results: The EC of rocuronium (EC50, EC90, and EC95) decreased significantly in accordance with increasing temperature. The groups at $36^{\circ} \mathrm{C}$ and $40^{\circ} \mathrm{C}$ showed clear differences in all areas (all $P<0.001$ ). Moreover, the $\mathrm{T} 1$ height (\%) and the duration index upon sugammadex administration showed faster recovery results in the $36^{\circ} \mathrm{C}$ than the $38^{\circ} \mathrm{C}$ and $40^{\circ} \mathrm{C}$ groups.
\end{abstract}

Conclusion: A rise of temperature from $38^{\circ} \mathrm{C}$ to $40^{\circ} \mathrm{C}$ in rat PNHD preparations proportionally enhanced the $\mathrm{NMB}$ induced by rocuronium. In addition, equimolar doses of sugammadex to the administered rocuronium showed a slower recovery time as the temperature rises.

Keywords: Antagonist, Sugammadex, Neuromuscular blockade, Rocuronium, Hyperthermia

\footnotetext{
* Correspondence: hsyang@amc.seoul.kr

${ }^{5}$ Department of Anesthesiology and Pain Medicine, Sun General Hospital, Daejeon, Republic of Korea

Full list of author information is available at the end of the article
}

(C) The Author(s). 2020 Open Access This article is licensed under a Creative Commons Attribution 4.0 International License, which permits use, sharing, adaptation, distribution and reproduction in any medium or format, as long as you give appropriate credit to the original author(s) and the source, provide a link to the Creative Commons licence, and indicate if changes were made. The images or other third party material in this article are included in the article's Creative Commons licence, unless indicated otherwise in a credit line to the material. If material is not included in the article's Creative Commons licence and your intended use is not permitted by statutory regulation or exceeds the permitted use, you will need to obtain permission directly from the copyright holder. To view a copy of this licence, visit http://creativecommons.org/licenses/by/4.0/ The Creative Commons Public Domain Dedication waiver (http://creativecommons.org/publicdomain/zero/1.0/) applies to the data made available in this article, unless otherwise stated in a credit line to the data. 


\section{Background}

In general, body temperature decreases during anesthesia due to the administration of anesthetic agents and the environment of the operating room $[1,2]$. Cases of hyperthermia exceeding the range of normal body temperature during general anesthesia are relatively infrequent [3]. Changes in body temperature during an operation result in changes in the pharmacodynamics of drugs such as neuromuscular blocking agents or agents that reverse neuromuscular blockade (NMB) such as sugammadex. Therefore, the use of these drugs requires an abundance of caution during emergencies requiring anesthesia.

However, clinical studies investigating hyperthermia are still unavailable and large-scale investigations are not feasible due to ethical constraints. Therefore, we designed specific environmental conditions at hyperthermic temperatures of $38{ }^{\circ} \mathrm{C}$ and $40{ }^{\circ} \mathrm{C}$ under in vitro conditions to demonstrate the effects of rocuronium and sugammadex using the phrenic nerve hemidiaphragm (PNHD) of rats.

\section{Methods}

\section{Ethical statement}

After ethical approval was granted by the Institutional Animal Care and Use Committee of Asan Medical Centre, Seoul, South Korea (approval number 2016-13067 on 3 March 2016; Chairperson Professor Jong Yeun Park), 33 male Sprague-Dawley rats weighing 238-256 g were provided by the Animal Care and Use of Asan Medical Centre, College of Medicine, University of Ulsan (Seoul, Korea).

A random number was generated using the Microsoft Office Excel 2013 program.

All mice were bred in the laboratory animal breeding room at the Laboratory Animal Research Center, Asan Institute for Lifesciences. The animals were housed in an individually ventilated cage system (Tecniplast, USA) under specific pathogen-free conditions with a 12-h light/12-h dark cycle (from 8 am to $8 \mathrm{pm}$ ) at the following conditions: temperature $22 \pm 1{ }^{\circ} \mathrm{C}$, humidity $50 \pm$ $10 \%$, laboratory rodent chow, and reverse osmotic water.

\section{Experimental procedures}

Thirty-three rats were randomly assigned to three groups at different temperatures $\left(36^{\circ} \mathrm{C}, 38^{\circ} \mathrm{C}\right.$, and $40{ }^{\circ} \mathrm{C}$; each group, $n=11)$. Sorting was accomplished using a random number generator in Microsoft Excel 2013 (Microsoft, Redmond, WA, USA). The rats were anesthetized via intraperitoneal injection of $30 \mathrm{mg} / \mathrm{kg}$ zoletil 50 (Virbac, Carros, France). Each anesthetized rat was bled and the diaphragm was extracted after checking for cardiac arrest. The thoracic cages were separated en bloc, and the left phrenic nerve-hemidiaphragm (PNHD) was prepared. The phrenic nerve-hemidiaphragm was fixed vertically in a $75 \mathrm{~mL}$ organ bath containing Krebs buffer ( $\mathrm{pH} 7.4 ; \mathrm{NaCl} 118 \mathrm{mM}, \mathrm{KCl} 5.0 \mathrm{mM}, \mathrm{CaCl} 22.5$ mM, NaHCO3 30 mM, KH2PO4 1.0 mM, MgSO4 1.0 $\mathrm{mM}$, and glucose $11.4 \mathrm{mM})$. The bath was preserved at $36^{\circ} \mathrm{C}, 38^{\circ} \mathrm{C}$, or $40^{\circ} \mathrm{C}$ via external warm water circulation before fixing the PNHD followed by continuous inflow of $95 \% \mathrm{O} 2$ and 5\% CO2 into the Krebs solution. A rib of each specimen was connected to bipolar platinum electrodes. The tendinous portion of the hemidiaphragm was connected to a force-displacement transducer (Grass FT03, Grass Instrument Co., Quincy, Massachusetts, USA) to measure isometric contraction at a resting tension of $2 \mathrm{~g}$ using a nerve stimulator (S88, Grass Instrument Co., Quincy, Massachusetts, USA). A stimulus isolation unit (SIU5, Grass Instrument Co. Quincy, Massachusetts, USA) with train of four (TOF) pulses of $2 \mathrm{~Hz}$ was also used to provide a supramaximal stimulation of $0.2 \mathrm{~ms}$ pulse duration at intervals of $20 \mathrm{~s}$. The muscle contraction responses were registered and digitized with a Power Lab acquisition system and stored on a computer using data charting software (LabChart, ADInstruments).

In all groups, after more than 30 min of stabilization, the contraction response to initial TOF stimulation, the height of the first twitch, and TOF ratio were measured. At least $20 \mathrm{~min}$ was allowed to achieve a stable state before rocuronium was added to the organ bath at an initial loading dose of $200 \mathrm{mcg}$. The T1 heights just before the addition of rocuronium served as the control values for each group. A booster dose of $150 \mathrm{mcg}$ was cumulatively added every $10 \mathrm{~min}$ until the first twitch response disappeared completely. The concentrations of rocuronium that generated depression of the first twitch to 5, $10,25,50,75,90$, and $95 \%$ of control were defined as the effective concentrations (EC) of rocuronium, ranging from EC5 to EC95. All the experimental drugs were injected into the chamber using an air displacement micropipette, and $10 \mathrm{~min}$ after the $\mathrm{T} 1$ height was completely suppressed, equimolar doses of sugammadex were injected into the organ bath to evaluate the recovery of diaphragmic muscle contractions. The T1 height and the TOF ratio (TOFR) at every $5 \mathrm{~min}$ until $30 \mathrm{~min}$ recovery was observed after the administration of sugammadex and defined as the recovery period. The following parameters were measured: the time for the first twitch to $25 \%$ of the control (duration, 25\%); the time to recovery of the first twitch from 25 to $75 \%$ of the control (duration, 25 to $75 \%$ ); the recovery index (the time to recovery from 25 to $75 \%$ of the control value of $\mathrm{T} 1$ height); the time taken for $\mathrm{T} 1$ to attain $95 \%$ of the control T1 height (the 95\% T1 time); the time taken for the TOFR to reach 0.9 (the TOFR 0.9 time); and the number of samples that failed to reach TOFR 0.9 in each group. 


\section{Statistical plan}

To determine the required sample size, the time from sugammadex administration to TOFR 0.9 in three groups $\left(36^{\circ} \mathrm{C}, 38^{\circ} \mathrm{C}\right.$, and $40^{\circ} \mathrm{C}$ in the organ bath, each $n=3$ ) was measured in a pilot study. The time for the three groups was $18.8 \pm(3.2), 25.2 \pm$ (4.3), and $25.9 \pm$ (3.0) min, respectively $\left(36^{\circ} \mathrm{C}, 38^{\circ} \mathrm{C}\right.$, and $40^{\circ} \mathrm{C}$, respectively).

The effect size (f) calculated using Cohen's formula was $0.6 . R$, indicating that 10 specimens in each group yielded $\alpha=0.05$, power $=0.8$, and $f=0.6$. We used 11 specimens in each group to compensate for dropout.

The results are expressed as mean \pm SD. Normality of the continuous variables was assessed using the ShapiroWilk test. Differences in the doses of rocuronium administered, ECs, T1 height (\%), TOFR (\%), 95\% T1 times, and TOFR 0.9 times among the groups were assessed using Kruskal-Wallis test with Bonferroni correction. The ECs of rocuronium were calculated via nonlinear regression analysis. All statistical analyses were conducted with the aid of $\mathrm{SPSS}^{\circ}$ software (ver. 18.0, SPSS Inc., USA). $P$ values $<0.05$ were regarded as statistically significant.

\section{Results}

The mean size and weight of the PNHD tissue preparations of the groups at $36^{\circ} \mathrm{C}, 38^{\circ} \mathrm{C}$, and $40^{\circ} \mathrm{C}$ were not different (Table 1). Comparison of the rocuronium concentration responses revealed that the T1 height (\%) exhibited a significant decline as the temperature increased in the $36^{\circ} \mathrm{C}, 38^{\circ} \mathrm{C}$, and $40^{\circ} \mathrm{C}$ groups, especially the groups at $36^{\circ} \mathrm{C}$ and $40^{\circ} \mathrm{C}$, which showed clear differences in all areas $(P=0.019)$ (Fig. 1). The cumulative concentration-response curves of rocuronium for the three groups shifted to the left as the temperature increased by $2{ }^{\circ} \mathrm{C}$.

Differences existed in effective concentration (EC) between the three groups (all $p<0.0015$ ) (Table 2). The EC50 of rocuronium was significantly reduced in the $40^{\circ} \mathrm{C}$ group compared with the groups at $36^{\circ} \mathrm{C}$ and $38^{\circ} \mathrm{C}(P=0.0005$ and $P=0.0356$, respectively). As the temperature increased, the EC10, EC25, EC50, EC75, EC90, and EC95 of rocuronium significantly decreased in the group at $40{ }^{\circ} \mathrm{C}$ compared with the group at $36{ }^{\circ} \mathrm{C}$ (all $P<0.001$ ). A significant difference was observed between the groups at $38^{\circ} \mathrm{C}$ and $40{ }^{\circ} \mathrm{C} \quad(P=0.045)$, although it was smaller than the difference between the groups at $36^{\circ} \mathrm{C}$ and $40^{\circ} \mathrm{C}$.

Measurement of the T1 height (\%)after the administration of sugammadex at doses equimola to the rocuronium revealed that the group at $36^{\circ} \mathrm{C}$ showed significantly faster recovery than did the groups at $38^{\circ} \mathrm{C}$ and $40{ }^{\circ} \mathrm{C}(P=0.011, P<0.001$, respectively) (Fig. 2). The groups at $38^{\circ} \mathrm{C}$ and $40^{\circ} \mathrm{C}$ did not show substantial differences in the first $10 \mathrm{~min}$; however, after that the $\mathrm{T} 1$ heights of the group at $40^{\circ} \mathrm{C}$ were significantly shorter than those of the group at $38^{\circ} \mathrm{C}(p=0.01)$. Pair-wise comparisons showed no differences in the recovery of TOFR (\%) among the groups (Fig. 3).

The duration index (25to 75\%) was distinctly higher in the $36^{\circ} \mathrm{C}$ group than in the groups at $38^{\circ} \mathrm{C}$ and $40^{\circ} \mathrm{C}$ ( $P=0.0113$ and $P<0.0001$, respectively) (Table 3 ). The maximum T1 height during $30 \mathrm{~min}$ showed a significant shortening in the $40^{\circ} \mathrm{C}$ group compared with the groups at $36^{\circ} \mathrm{C}$ and $38^{\circ} \mathrm{C}$. All the samples reached TOFR 0.9 after sugammadex administration.

\section{Discussion}

During neuromuscular blockade of PNHD using rocuronium, the $\mathrm{T} 1$ height (\%) was significantly decreased as the temperature increased from $36^{\circ} \mathrm{C}$ to $40^{\circ} \mathrm{C}$ at same doses. The cumulative concentration-response curve of rocuronium in each group shifted to the left with every $2^{\circ} \mathrm{C}$ rise in temperature. Also, the $\mathrm{EC}$ of rocuronium decreased following the rise in temperature. Addition of equimolar doses of sugammadex to rocuronium resulted in a faster recovery in the $36^{\circ} \mathrm{C}$ group compared with the other groups. Also, the $\mathrm{T} 1$ heights (\%) of the $38^{\circ} \mathrm{C}$ and $40{ }^{\circ} \mathrm{C}$ groups failed to recover sufficiently for $30 \mathrm{~min}$.

Several factors contribute to a perioperative rise in body temperature. The general causes include fever associated with infection, blood transfusion mismatch, drug toxicity, and allergic reactions excluding genetic diseases such as malignant hyperthermia [3]. Moreover, hyperthermia can easily occur in infants upon excessive heating when core temperature monitoring devices are not used [4].

Analysis of the effects of NMB agents on hyperthermia is complicated by two factors. The effects of higher body temperature on NMB need to be distinguished from those of NMB agents. Also, the distinct role of each of

Table 1 The mean size and weight of the phrenic nerve-diaphragm tissue

\begin{tabular}{lllll}
\hline Group & Rat body weight(g) & Hemi-diaphragm mass $(\mathrm{mg})$ & Hemi-diaphragm length $(\mathrm{mm})$ & Hemi-diaphragm width $(\mathrm{mm})$ \\
\hline $36^{\circ} \mathrm{C}(n=11)$ & $245.7(65.3)$ & $168.8(49.3)$ & $10.2(1.3)$ & $19.3(2.7)$ \\
$38^{\circ} \mathrm{C}(\mathrm{n}=11)$ & $256.8(34.2)$ & $163.9(29.6)$ & $9.6(0.9)$ & $20.1(3.4)$ \\
$40^{\circ} \mathrm{C}(\mathrm{n}=11)$ & $238(18.9)$ & $152(25.3)$ & $8.8(1.1)$ & $17.2(2.1)$ \\
\hline
\end{tabular}

Data are expressed as mean \pm SD 


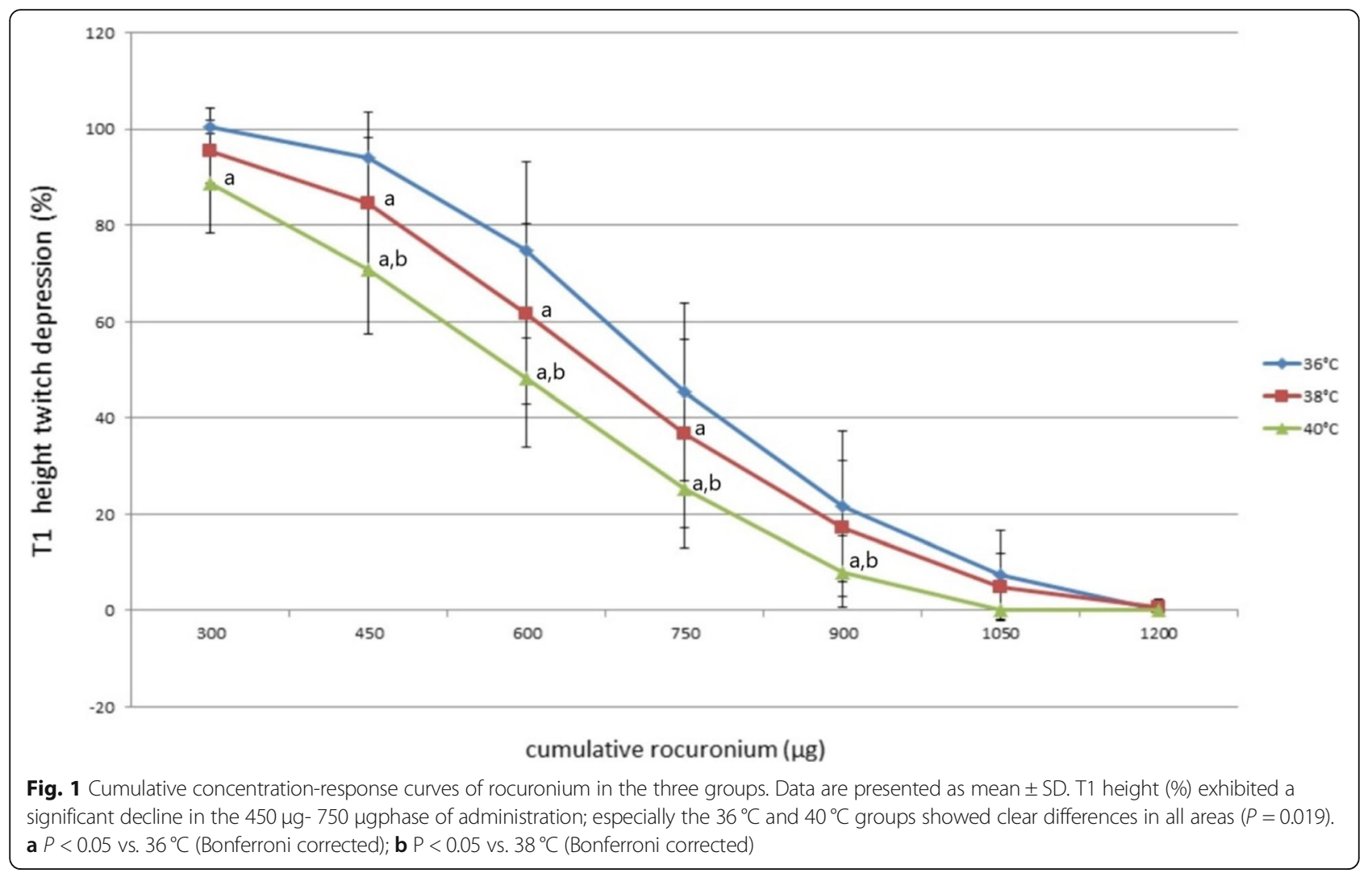

the pharmacokinetic and pharmacodynamic factors should be elucidated.

The tension associated with a muscular twitch involves two components: internal shortening and relaxation decay [5]. The reaction decreases in accordance with decreasing temperature [6]. Therefore, at a lower temperature, the interaction between actin and myosin filaments is delayed, which is related to a temperature-dependent removal of intracellular calcium [7, 8]. Increasing the muscle temperature to the level of core temperature resulted in a decrease in calcium sensitivity and increase in reactive oxygen species level $[9,10]$. Changes in calcium sensitivity and reactive oxygen species can affect both pre- and postsynaptic sites $[11,12]$. Thus, changes in twitch tension can arise depending on varying levels of temperature in cases unexposed to NMB agents. However, data on human neuromuscular junctions at temperatures above $36^{\circ} \mathrm{C}$ are not sufficient yet.

Our findings only pertain to the effect of temperature on muscle tension and contraction. In vivo physiological changes due to hyperthermia during the perioperative period, such as altered cardiac output and changes in regional blood flow may induce changes in drug metabolism. Furthermore, changes in temperature can alter the

Table 2 Comparisons of effective concentration of rocuronium

\begin{tabular}{|c|c|c|c|c|c|c|c|}
\hline & $36^{\circ} \mathrm{C}$ & $38^{\circ} \mathrm{C}$ & $40^{\circ} \mathrm{C}$ & $P$-value among all the groups & 36 vs. 38 & 38 vs. 40 & 36 vs 40 \\
\hline$\overline{\mathrm{EC} 5}(\mu \mathrm{g} / \mathrm{m \ell})$ & $5.3(1.3)^{a}$ & $4.2(1.2)$ & $3.1(1.0)^{c}$ & 0.0014 & 0.048 & 0.066 & 0.0006 \\
\hline EC10 & $5.8(1.2)$ & $4.8(1.2)$ & $3.7(1.0)^{c}$ & 0.0014 & 0.056 & 0.056 & 0.0006 \\
\hline EC25 & $6.5(1.1)$ & $5.6(1.1)^{\mathrm{b}}$ & $4.5(0.9)^{c}$ & 0.0015 & 0.087 & 0.041 & 0.0006 \\
\hline EC50 & $7.2(1.0)$ & $6.4(1.1)^{b}$ & $5.3(0.8)^{c}$ & 0.0014 & 0.115 & 0.035 & 0.0005 \\
\hline EC75 & $7.9(0.9)$ & $7.2(1.0)^{b}$ & $6.2(0.8)^{c}$ & 0.0014 & 0.167 & 0.035 & 0.0004 \\
\hline EC90 & $8.6(0.9)$ & $8.0(1.0)_{b}$ & $7.0(0.7)^{c}$ & 0.0011 & 0.131 & 0.035 & 0.0003 \\
\hline EC95 & $9.1(0.8)$ & $8.5(1.0)^{b}$ & $7.6(0.6)^{c}$ & 0.0015 & 0.167 & 0.048 & 0.0003 \\
\hline
\end{tabular}

Values presented as mean (SD). EC, effective concentration

${ }^{\text {a }} \mathrm{P}$ value less than $36^{\circ} \mathrm{C}$ vs. $38^{\circ} \mathrm{C}$

bP value less than $38^{\circ} \mathrm{C}$ vs. $40^{\circ} \mathrm{C}$

${ }^{\mathrm{C}} \mathrm{P}$ value less than $36^{\circ} \mathrm{C}$ vs. $40^{\circ} \mathrm{C}$ 


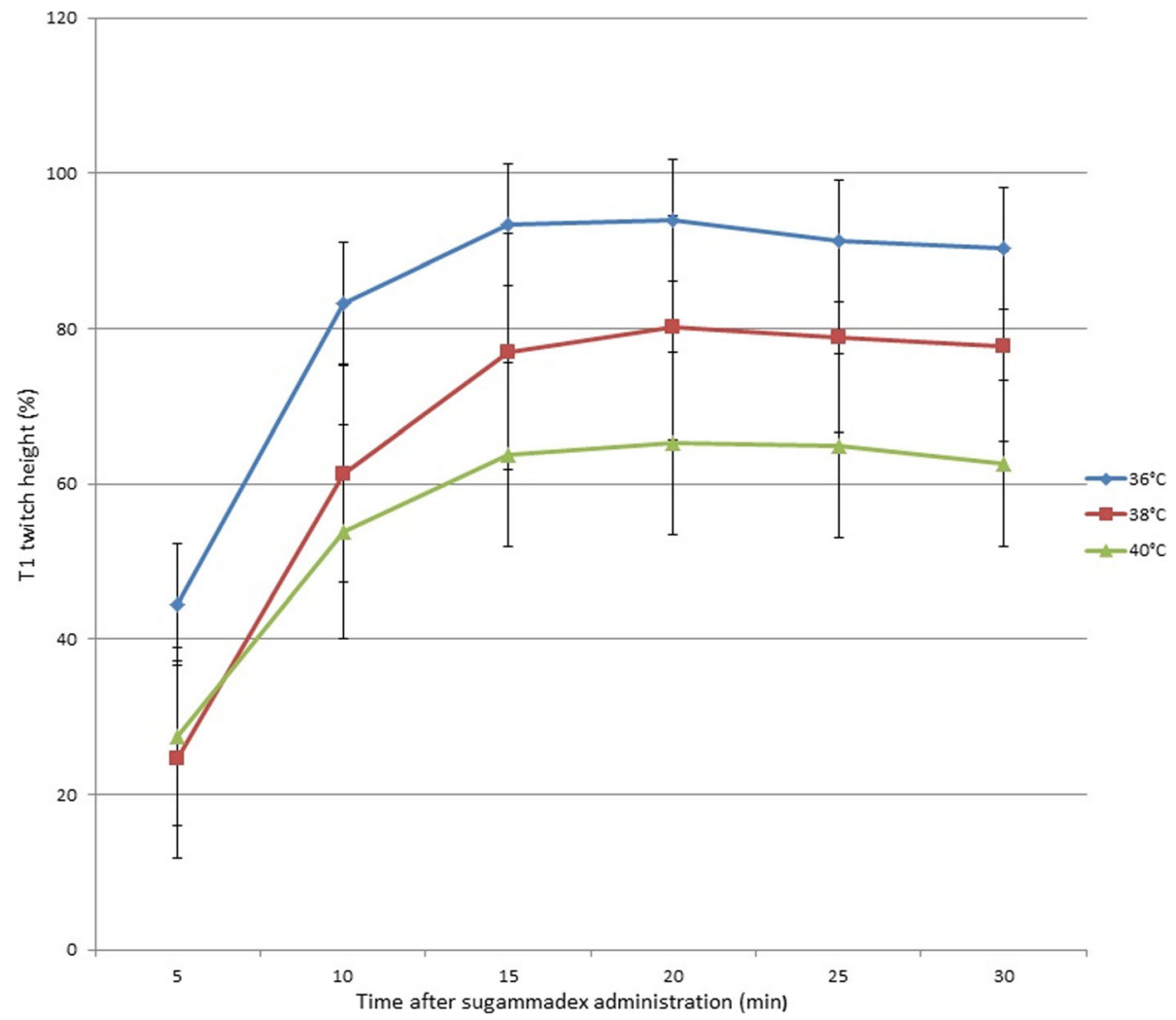

Fig. 2 Changes in the $\mathrm{T} 1$ height (\%) duration during the 30 min recovery period significantly differed between the groups. The group at $36^{\circ} \mathrm{C}$ showed increased recovery than did the groups at $38^{\circ} \mathrm{C}$ and $40^{\circ} \mathrm{C}(P=0.011, P<0.001$ respectively)

pharmacokinetics and pharmacodynamics of NMB and reversal agents $[13,14]$. Under hypothermia, the duration of NMB in humans is prolonged $[15,16]$. Similarly, hyperthermia has been reported to shorten NMB duration, possibly due to increased hepatic uptake [17]. While in vitro methodologies have been shown to distinguish the effects on muscle physiology from pharmacokinetic and dynamic factors, the interplay between these factors and those identified in vitro is unknown in an intact organism.

We used an equimolar dose of sugammadex to determine the effect of hyperthermia on the reversal of NMB. Few studies have explored the pharmacodynamics of sugammadex in hyperthermia. However, in a previous study in which NMBs were induced by rocuroniumin in two groups of patients, one normothermic and one hypothermic, and the patients were treated with sugammadex, the group with slight hypothermia $\left(34.5-35^{\circ} \mathrm{C}\right)$ and the group at normal temperature $\left(36.5-37^{\circ} \mathrm{C}\right)$ experienced reversal from a state of deep NMB (PTC 1-2) following sugammadex $(4.0 \mathrm{mg} / \mathrm{kg})$ treatment, with a faster recovery of the normal group by $46 \mathrm{~s}$ compared with the hypothermia group [18]. The investigators reported that the difference was caused by decreased plasma clearance in the low-temperature group although their study lacked clinical significance. Based on this finding, we predicted that our results would show a similar recovery in the hyperthermia group compared with the normal temperature group when NMB was reversed by sugammadex. However, it was found that the recovery of the $36^{\circ} \mathrm{C}$ group was significantly faster compared with the $38^{\circ} \mathrm{C}$ and $40^{\circ} \mathrm{C}$ groups. In addition, the recovery index was faster in the $36^{\circ} \mathrm{C}$ group compared with the other groups. Moreover, theT1 heights (\%) of the $38^{\circ} \mathrm{C}$ and $40^{\circ} \mathrm{C}$ groups did not recover adequately for $30 \mathrm{~min}$. Nevertheless, the time taken to reach TOFR 0.9 was not influenced by temperature. Interestingly, similar to clinical recovery of NMB with a low dose of sugammadex, the T1 height (\%) peaked earlier, and the TOFR 0.9 was observed later [19]. It can be assumed that free rocuronium, which is not removed by sugammadex, binds to postsynaptic acetylcholine receptors more strongly during the recovery period $[20,21]$. It is possible that hyperthermia may have interfered with the combination of sugammadex and rocuronium.

It is speculated that the function of acetylcholine or cholinesterase is probably affected by hyperthermia. However, other studies using the PNHD of rats showed an increase in temperature up to $43^{\circ} \mathrm{C}$ following muscle usage or environmental factors [22], and the threshold 


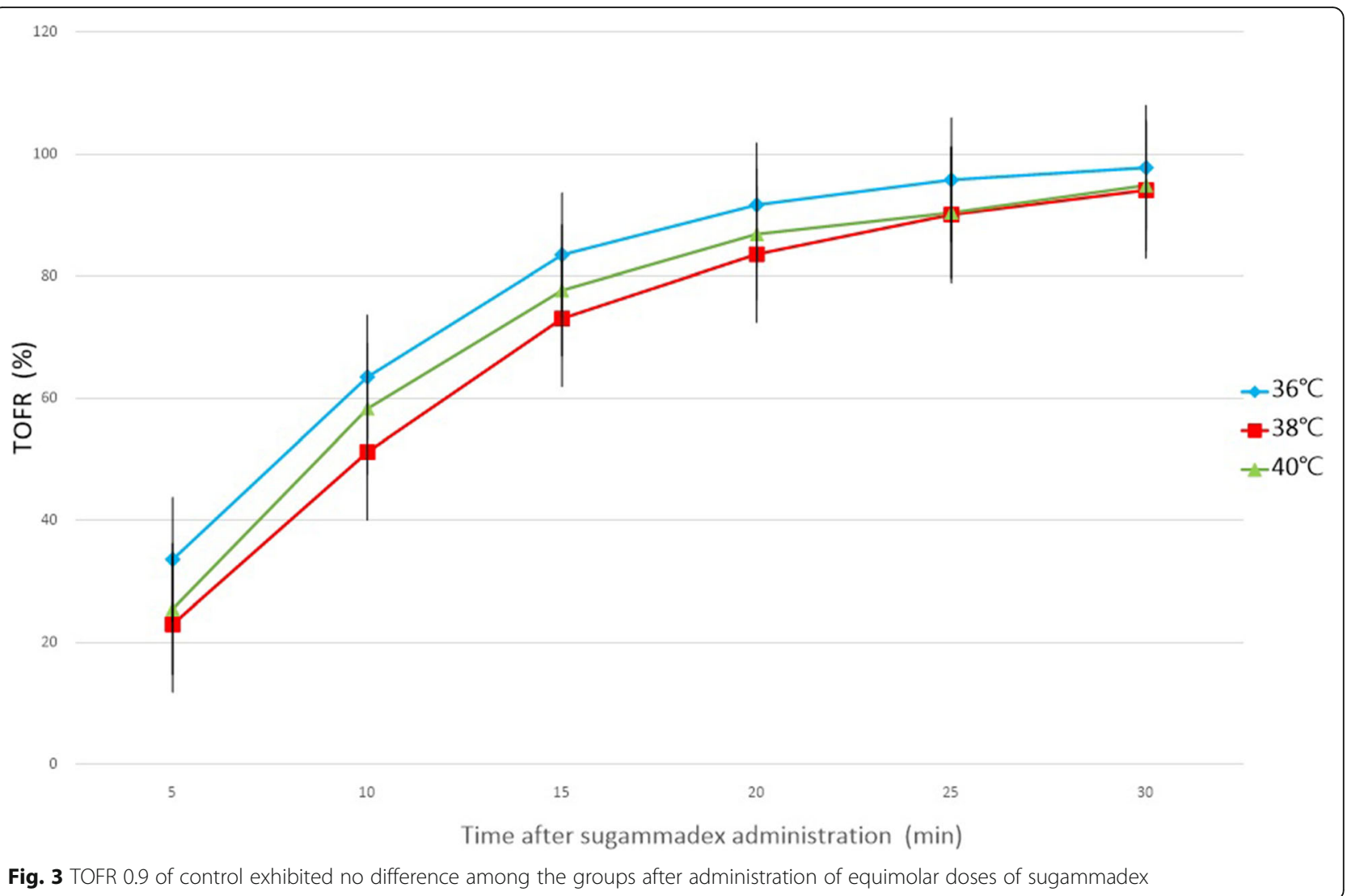

value of temperature that can be reversed without damage was $45.3^{\circ} \mathrm{C}$, which is consistent with the experimental conditions [23]. In addition, the acetylcholine association and dissociation rate constants were independent at a wide range of temperatures [24]. Therefore, the temperature range of $38^{\circ} \mathrm{C}$ to $40^{\circ} \mathrm{C}$ does not have a significant effect on the function of acetylcholine.

The study had the following limitations: First, it was an in vitro test that failed to analyze pharmacodynamic and pharmacokinetic effects simultaneously; second, it failed to monitor the histological and pathophysiological changes of muscles induced by changes in temperature.

Table 3 Twitch height and train-of-four ratio after the addition of sugammadex

\begin{tabular}{llll}
\hline & $36^{\circ} \mathrm{C}$ & $38^{\circ} \mathrm{C}$ & $40{ }^{\circ} \mathrm{C}$ \\
\hline Maximum T1 height & $16.1(3.7)$ & $16.5(4.1)$ & $13.1(2.6)$ \\
Dur 25 (\%) min & $2.1(0.8)$ & $2.7(0.8)$ & $5.0(1.7)$ \\
Dur 25 75 (\%) min & $3.7(1.3)$ & $4.7(0.8)$ & $5.1(1.0)$ \\
TOFR (\%) in 30 min & $97.8(3.6)$ & $94.1(6.0)$ & $94.9(5.8)$ \\
Maximal TOF ratio < 0.9(n) & 0 & 0 & 0 \\
\hline
\end{tabular}

Values are expressed as mean $\pm(\mathrm{SD})$ or number, TOF: train-of-four, $\mathrm{T} 1$ height of train-of-four, Dur 25\%: time from reversal to recovery of T1 to $25 \%$, Dur 25 to $75 \%$ : time to recovery of $\mathrm{T} 1$ from 25 to $75 \%$

\section{Conclusion}

An increase in temperature from $38^{\circ} \mathrm{C}$ to $40^{\circ} \mathrm{C}$ in rat PNHD preparations proportionally enhanced the NMB induced by rocuronium. In addition, equimolar doses of sugammadex to the administered rocuronium showed a slower recovery time as the temperature increased.

\section{Abbreviations}

NMB: neuromuscular blockade; PNHD: phrenic nerve hemidiaphragm; TOF: train-of-four; EC: effective concentration; TOFR: train-of-four ratio

\section{Acknowledgements}

Not applicable.

\section{Authors' contributions}

HSY and YBK were responsible for the study design. YMK, JMC and HSY performed the study. JSS analyzed the data. HJK made substantial contributions to the interpretation of the data. JSK wrote this manuscript under the supervision of HSY. All authors read and approved the final manuscript.

\section{Funding}

Not applicable.

\section{Availability of data and materials}

The datasets used and/or analyzed during the current study are available from the corresponding author upon reasonable request.

\section{Ethics approval and consent to participate}

This study was approved by the Institutional Animal Care and Use Committee of Asan Medical Centre, Seoul, South Korea (approval number 2016-13-067 on 3 March 2016; Chairperson Professor Jong Yeun Park).Thirty- 
three male Sprague-Dawley rats weighing $238-256 \mathrm{~g}$ were provided by the Animal Care and Use Committee of Asan Medical Centre, College of Medicine, University of Ulsan (Seoul, Korea).

\section{Consent for publication}

Not applicable.

\section{Competing interests}

The authors declare that they have no competing interests.

\section{Author details}

'Department of Anesthesiology and Pain Medicine, Gangneung Asan Hospital, College of Medicine, University of Ulsan, Gangwon, Republic of Korea. ${ }^{2}$ Department of Anesthesiology and Pain Medicine, Asan Medical Center, College of Medicine, University of Ulsan, Seoul, Republic of Korea. ${ }^{3}$ Deaprtment of Anesthesiology and Pain Medicine, Gil Medical Center, College of Medicine, Gacheon University, Incheon, Republic of Korea. ${ }^{4}$ Department Preventive medicine \& Public Health Catholic Kwandong University, Gangneung, Republic of Korea. ${ }^{5}$ Department of Anesthesiology and Pain Medicine, Sun General Hospital, Daejeon, Republic of Korea.

\section{Received: 28 October 2019 Accepted: 29 July 2020}

Published online: 07 August 2020

\section{References}

1. Sessler DI. Mild perioperative hypothermia. N Engl J Med. 1997:336:1730-7. https://doi.org/10.1056/NEJM199706123362407.

2. Heier T, Caldwell JE. Impact of hypothermia on the response to neuromuscular blocking drugs. Anesthesiology. 2006;104:1070-80. https:// doi.org/10.1097/00000542-200605000-00025.

3. Sessler DI. Temperature monitoring and perioperative thermoregulation. Anesthesiology. 2008;109:318-38. https://doi.org/10.1097/ALN. 0b013e31817f6d76.

4. Frank SM, Kluger MJ, Kunkel SL. Elevated thermostatic setpoint in postoperative patients. Anesthesiology. 2000;93:1426-31. https://doi.org/10. 1097/00000542-200012000-00014

5. Hill AV. The influence of temperature on the tension developed in an isometric twitch. Proceedings of the Royal Society of London. Series B Biological Sciences. 1951;138:349-54.

6. Friess $\mathrm{SL}$, Weissberger $\mathrm{A}$. Investigation of rates and mechanisms of reactions (technique of organic chemistry volume VIII). 1st ed. New York: Interscience Publishers; 1953.

7. Hubbard JI, Jones SF, Landau EM. The effect of temperature change upon transmitter release, facilitation and post-tetanic potentiation. J Physiol. 1971; 216:591-609. https://doi.org/10.1113/jphysiol.1971.sp009542.

8. Ward D, Crowley WJ, Johns TR. Effect of temperature at the neuromuscular transmission. Am J Phys. 1972;222:216-9. https://doi.org/10.1152/ajplegacy, 1972.222.1.216.

9. Moopanar TR, Allen DG. Reactive oxygen species reduce myofibrillar Ca2+ sensitivity in fatiguing mouse skeletal muscle at $37^{\circ} \mathrm{C}$. J Physiol. 2005;564(1): 189-99. https://doi.org/10.1113/jphysiol.2005.083519.

10. Bennett AF. Temperature and muscle. J Exp Biol. 1985;115:333-44.

11. Darnley GM, Duke AD, Steele DS, MacFarlane NG. Effects of reactive oxygen species on aspects of excitation-contraction coupling in chemically skinned rabbit diaphragm muscle fibres. Exp Physiol. 2001;86(2):161-8. https://doi. org/10.1113/eph8602109

12. Brotto MA, Nosek TM. Hydrogen peroxide disrupts Ca2+ release from the sarcoplasmic reticulum of rat skeletal muscle fibers. J Appl Physiol. 1996; 81(2):731-7. https://doi.org/10.1152/jappl.1996.81.2.731.

13. Caldwell JE, Heier T, Wright PM, Lin S, McCarthy G, Szenohradszky J, Sharma ML, Hing JP, Schroeder M, Sessler DI. Temperature-dependent pharmacokinetics and pharmacodynamics of vecuronium. Anesthesiology. 2000;92(1):84-93. https://doi.org/10.1097/00000542-200001000-00018.

14. De Witte J, Sessler DI. Perioperative shivering: physiology and pharmacology. Anesthesiology. 2002;96:467-84. https://doi.org/10.1097/ 00000542-200202000-00036.

15. Heier T, Caldwell JE, Sessler DI, Miller RD. Mild intraoperative hypothermia increases duration of action and spontaneous recovery of vecuronium blockade during nitrous oxide-isoflurane anesthesia in humans. Anesthesiology. 1991;74:815-9. https://doi.org/10.1097/00000542199105000-00003.
16. Heier T, Caldwell JE, Sharma ML, Gruenke LD, Miller RD. Mild intraoperative hypothermia does not change the pharmacodynamics (concentration-effect relationship) of vecuronium in humans. Anesth Analg. 1994;78(5):973-7. https://doi.org/10.1213/00000539-199405000-00024.

17. Adachi T, Shinomura T, Nomura R. Duration of vecuronium-induced neuromuscular blockade is shortened during hyperthermic intraoperative intraperitoneal chemotherapy. Br J Anaesth. 2003;91:160-1.

18. Lee HJ, Kim KS, Jeong JS, Kim KN, Lee BC. The influence of mild hypothermia on reversal of rocuronium-induced deep neuromuscular block with sugammadex. BMC Anesthesiol. 2015;15:7. https://doi.org/10.1186/ 1471-2253-15-7.

19. Staals LM, Driessen JJ, Van Egmond J, De Boer HD, Klimek M, Flockton EA, Snoeck MM. Train-of-four ratio recovery often precedes twitch recovery when neuromuscular block is reversed by sugammadex. Acta Anaesthesiol Scand. 2011:55:700-7. https://doi.org/10.1111/j.1399-6576.2011.02448.x.

20. Jonsson M, Gurley D, Dabrowski M, Larsson O, Johnson EC, Eriksson LI. Distinct pharmacologic properties of neuromuscular blocking agents on human neuronal nicotinic acetylcholine receptors: a possible explanation for the train-of-four fade. Anesthesiology. 2006;105:521-33. https://doi.org/ 10.1097/00000542-200609000-00016.

21. Gage PW, Hammill OP. Effects of anesthetics on ion channels in synapses. Int Rev Neurophysiol. 1981;25:1-45.

22. Furuyama F. Strain difference in thermoregulation of rats surviving extreme heat. J Appl Physiol Respir Environ Exerc Physiol. 1982;52:410-5. https://doi. org/10.1152/jappl.1982.52.2.410.

23. Seese TM, Harasaki H, Saidel GM, Davies CR. Characterization of tissue morphology, angiogenesis, and temperature in the adaptive response of muscle tissue to chronic heating. Lab Investig. 1998;78:1553-62.

24. Shaweta G, Anthony A. Temperature dependence of acetylcholine receptor channels activated by different agonists. Biophys J. 2011;100(4):895-903. https://doi.org/10.1016/j.bpj.2010.12.3727.

\section{Publisher's Note}

Springer Nature remains neutral with regard to jurisdictional claims in published maps and institutional affiliations.
Ready to submit your research? Choose BMC and benefit from:

- fast, convenient online submission

- thorough peer review by experienced researchers in your field

- rapid publication on acceptance

- support for research data, including large and complex data types

- gold Open Access which fosters wider collaboration and increased citations

- maximum visibility for your research: over $100 \mathrm{M}$ website views per year

At $\mathrm{BMC}$, research is always in progress.

Learn more biomedcentral.com/submissions 